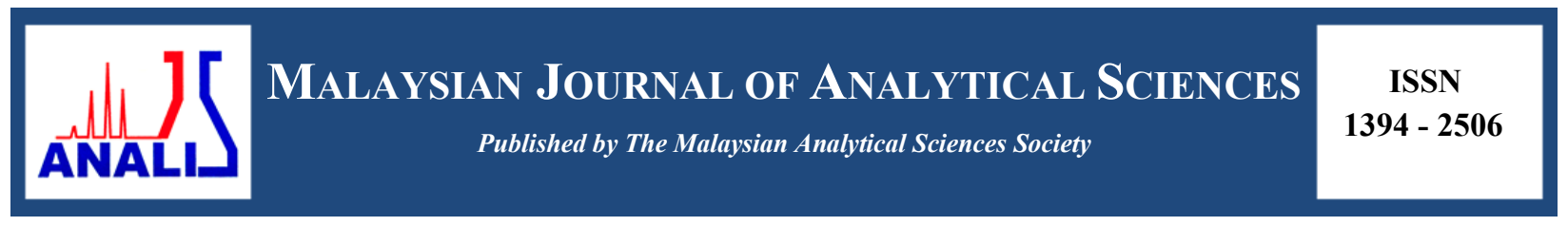

\title{
INTERACTION OF N,N'-BIS[4-[1-(2-HYDROXYETHOXY)] SALICYLIDENE]-PHENYLDIAMINE-NICKEL(II) AND COPPER(II) COMPLEXES WITH G-QUADRUPLEX DNA
}

\author{
(Interaksi Antara Kompleks N, N'-Bis [4- [1- (2-Hidroksietoksi)] Saliksalidin]-Fenildiamina- \\ Nikel(II) dan Kuprum(II) Bersama DNA G-Kuadrupleks)
}

Roshatiara Shamsuddin, Muhammad Ameerullah Sahudin, Nur Hasyareeda Hassan, Nurul Huda Abd Karim*

School of Chemical Sciences and Food Technology, Faculty of Science and Technology, Universiti Kebangsaan Malaysia, 43600 UKM Bangi, Selangor, Malaysia

*Corresponding author: nurulhuda@ukm.edu.my

Received: 29 December 2016; Accepted: 28 March 2017

\begin{abstract}
Binding studies of metal complexes with DNA has attracted many interests due to their importance in cancer therapy and molecular biology. In this study, N,N'-bis[4-[1-(2-hydroxyethoxy)] salicylidene]-phenyldiamine and its metal $\mathrm{Ni}$ (II) and $\mathrm{Cu}$ (II) complexes have been synthesized and characterized. The complexes were structurally characterized using standard spectroscopic 1D ${ }^{1} \mathrm{H}, 2 \mathrm{D}$ COSY, HMQC and ${ }^{13} \mathrm{C}$ NMR spectroscopy, FTIR spectroscopy and ESI-MS spectrometry. The binding interaction between synthesized metal complexes and G-quadruplex DNA has been investigated using UV/Vis DNA titration study. Ni(II) and $\mathrm{Cu}(\mathrm{II})$ complexes bind strongly to G-quadruplex DNA $\left(\mathrm{Kb}=(5.42 \pm 2.48) \times 10^{6} \mathrm{M}^{-1}\right.$ and $(1.42 \pm 2.48) \times 10^{6} \mathrm{M}^{-1}$ respectively) via end stacking mode. Both complexes show selectivity for G-quadruplex DNA over CT- DNA by 2.15- and 1.82fold, respectively.
\end{abstract}

Keywords: metal complexes, DNA binding, G-quadruplex DNA

\section{Abstrak}

Kajian mengenai pengikatan kompleks logam bersama DNA telah menarik perhatian penyelidik disebabkan kepentingannya dalam perubatan terapi kanser dan molekular biologi. Dalam kajian ini, N, N'-bis [4-[1-(2-hidroksietoksi)] saliksalidin]fenildiamina bersama logam $\mathrm{Ni}(\mathrm{II})$ dan $\mathrm{Cu}$ (II) kompleks telah berjaya disintesis dan dicirikan. Struktur kompleks telah dicirikan menggunakan spektroskopi piawai 1D ${ }^{1} \mathrm{H}, 2 \mathrm{D}$ COSY, HMQC dan spektroskopi ${ }^{13} \mathrm{C}$ NMR, spektroskopi FTIR dan spektrometri ESI-MS. Pengikatan antara kompleks logam yang disintesis bersama DNA G-kuadrupleks telah dikaji dengan menggunakan kajian titratan DNA UV/Vis. Ni(II) dan Cu(II) kompleks memberikan nilai ikatan yang tinggi kepada DNA G-kuadrupleks ((5.42 $\pm 2.48) \times 10^{6} \mathrm{M}^{-1}$ dan $\left.(1.42 \pm 2.48) \times 10^{6} \mathrm{M}^{-1}\right)$ melalui mod penyusunan akhir. Ni(II) dan $\mathrm{Cu}$ (II) kompleks menunjukkan pemilihan pengikatan terhadap G-kuadrupleks DNA berbanding CT- DNA dengan 2.15 dan 1.82 kali ganda setiap satu.

Kata kunci: kompleks logam, pengikatan DNA, DNA G-kuadrupleks

\section{Introduction}

Over this past two decades, DNA have been regarded as primary molecular target for antitumor and antimicrobial drugs [1]. Recently, G-quadruplex DNA have been proposed to be alternative and attractive targets for the development of anticancer drugs. G-quadruplex DNA are found in biologically important regions such as protooncogene promoter region, immunoglobulin switch regions and telomeres [2]. Telomere is the end of chromosome 
DNA

consist of single strand of guanine-rich DNA sequence [3]. The guanine-rich sequences of DNA can fold into quadruply stranded structures known as G-quadruplex DNA [4]. Stabilization of quadruplex DNA by small molecules can inhibit telomerase, an enzyme overexpressed in $85-90 \%$ of cancerous cell which play important role in cancer cell immortalization [5]. Consequently, there is growing interest in development of G-quadruplex DNA stabilizers. Researchers are focusing on stabilizer that can bind to G-quadruplex DNA with high affinity and selectivity over duplex DNA. Organic compounds have been reported to be a good G-quadruplex DNA stabilizers such as such as anthracene, naphthalene, bipyridine or pyrine [6]. Most of G-quadruplex stabilizers share similar properties such as planar geometry to enable them to $\pi$ - $\pi$ stack on the surface of guanine quartet and high solubility in water [7].

Metal complexes have recently emerged to be a new class of G-quadruplex stabilizers. Thus far, metal complexes have included copper, platinum, manganese, nickel, zinc and ruthenium in their design [8-10]. A clear advantage of metal complexes over organic molecules is their varied geometry. The presence of metal ions play a vital role in coordinating ligands into the optimal geometry for G-quadruplex interaction. Metal centre also often possesses a positive charge, which can interact with the electron-rich channel at the centre of the G-quadruplex.

Nickel(II) and copper(II) salphen complexes had been synthesized before and showed ability to selectively stabilize G-quadruplex DNA [4]. Both complexes are reported to have planar geometry with aromatic group that allowed $\pi-\pi$ stacking interactions with G-quadruplex DNA [11]. In addition, the presence of substituents such as amines and amino acid group to the metal complexes gave high affinity when interact with G-quadruplex DNA [12]. This is because the substituents played an important role to increase the solubility of the complexes in aqueous media as well as enhancing their ability to bind to G-quadruplex DNA. The attachment of hydroxyl groups to metal complexes have been proposed before by Nurul Huda [13]. The presence of hydrogen bonding can increase the solubility of the complex in buffer and binding energy to G-quadruplex DNA. Thus, a successful strategy to improve the selectivity of complexes have included planar geometry to stack on the surface of guanine quartet and hydroxyl subtituents to improve the solubility of the complexes in water.

Research are still ongoing in finding G-quadruplex DNA with high affinity and selectivity towards G-quadruplex DNA. In this research, we report the synthesis of nickel(II) and copper(II) salphen complex with hydroxyl substituent in order to get good solubility and high binding energy with G-quadruplex DNA. To date, the synthesis and G-quadruplex DNA binding studies of the complexes have not been reported yet. The finding of the research could be useful in designing anticancer drug based on G-quadruplex DNA interaction.

\section{Chemicals}

\section{Materials and Methods}

The chemicals used in this work such as 1,2-phenyldiamine, 2,4-dihydroxybenzaldehyde, nickel(II) acetate tetrahydrate, copper(II) acetate hydrate, 2-chloroethanol and potassium carbonate were purchased from SigmaAldrich. Human Telomeric DNA (H-Telo) and Calf thymus DNA (CT-DNA) was purchased from Sigma (USA).

\section{Physical measurement}

The nuclear magnetic resonance (NMR) spectra were recorded in DMSO-d6 by using JEOL JNM-ECP $400 \mathrm{MHz}$ spectrometer. IR spectra were recorded using FTIR Perkin-Elmer GX Model in the spectral range of $4000-400 \mathrm{~cm}^{-}$ 1. The mass spectrometry were carried out using Electrospray ionization Mass Spectrometry Bruker Daltonics. DNA binding experiments were carried out in Tris-Potassium chloride (Tris-KCl) buffer at $\mathrm{pH} 7.4$ using PHM 210 measurement, while the UV/Vis absorption spectra were measured on a Shimadzu UV-1650 spectrophotometer using a $1 \mathrm{~mL}$ cuvette.

\section{Synthesis of N,N'-bis-4-(hydroxysalicylidene)-phenylenediamine-nickel(II) complex, [1]}

Complex [1] was prepared following previous work of the group [4, 14]. All spectroscopic data for the complex are in accordance to literature [14]. 1,2-Phenyldiamine $(0.135 \mathrm{~g}, 1.25 \mathrm{mmol})$ and 2,4-dihydroxybenzaldehyde $(0.345 \mathrm{~g}$, $2.50 \mathrm{mmol})$ were dissolved in methanol $(40 \mathrm{ml})$ and the reaction mixture was stirred at reflux for $30 \mathrm{~min}$. $\mathrm{Ni}(\mathrm{OAc})_{2} .4 \mathrm{H}_{2} \mathrm{O}(0.622 \mathrm{~g}, 2.50 \mathrm{mmol})$ was then added to mixture. A brick-red solid precipitated form immediately. 
The reaction was then heated at reflux for a further 4 hour. The solvents was filtered to get brick-red precipitate solid. The solid was washed with ethanol $(100 \mathrm{~mL})$, diethyl ether $(50 \mathrm{~mL})$ and water $(50 \mathrm{~mL})$.

Synthesis N,N'-bis[4-[1-(2-hydroxyethoxy)] salicylidene]-phenyldiamine-nickel(II) complex, [2]

Complex [2] was prepared following previous work of the group [14]. All spectroscopic data for the complex are in accordance to the literature. A complex nickel(II) salphen $(0.251 \mathrm{~g}, 0.62 \mathrm{mmol}), 2$-chloroethanol $(0.252 \mathrm{~g}, 3.09$ $\mathrm{mmol})$ and $\mathrm{K}_{2} \mathrm{CO}_{3}(0.691 \mathrm{~g}, 4.98 \mathrm{mmol})$ in DMF solutions $(30 \mathrm{~mL})$ was heated at $90{ }^{\circ} \mathrm{C}$ overnight. After that 2chloroethanol with the same mole was added and the reaction was heated for another 24 hours. After this time the excess salts were removed by filtration and the DMF evaporated under reduced pressure. The resulting dark red solid was recrystallised with DMF: diethylether (1:3) to give as brown red solid.

Synthesis of N,N'-bis-4-(hydroxysalicylidene)-phenylenediamine-copper(II) complex, [3]

Synthesis complex copper(II) salphens followed the published method [4]. 1,2-Phenyldiamine (0.135 g, $1.25 \mathrm{mmol})$ and 2,4-dihydroxybenzaldehyde $(0.345 \mathrm{~g}, 2.50 \mathrm{mmol})$ were dissolved in methanol $(40 \mathrm{~mL})$ and the reaction mixture was stirred at reflux for 30 minutes. $\left(\mathrm{CH}_{3} \mathrm{COO}\right)_{2} \mathrm{Cu}_{\mathrm{H}} \mathrm{H} \mathrm{O}(0.499 \mathrm{~g}, 2.50 \mathrm{mmol})$ was then added to mixture. A dark green solid precipitated form immediately. The reaction was then heated at reflux for a further 4 hours. The solvents was filtered to get dark green precipitate solid. The solid was washed with ethanol $(100 \mathrm{~mL})$, diethyl ether $(50 \mathrm{~mL})$ and water $(50 \mathrm{~mL})$.

Synthesis N,N'-bis[4-[1-(2-hydroxyethoxy)]salicylidene]-phenyldiamine-copper(II) complex, [4]

A complex copper(II) salphen $(0.253 \mathrm{~g}, 0.62 \mathrm{mmol})$, 2-chloroethanol $(0.252 \mathrm{~g}, 3.09 \mathrm{mmol})$ and $\mathrm{K}_{2} \mathrm{CO}_{3}(0.688 \mathrm{~g}$, $4.98 \mathrm{mmol})$ in DMF solutions $(30 \mathrm{~mL})$ was heated at $90{ }^{\circ} \mathrm{C}$ overnight. After that 2-chloroethanol with the same mole was added and the reaction was heated for another 24 hours. After this time the excess salts were removed by filtration and the DMF evaporated under reduced pressure. The resulting dark green solid was recrystallized with DMF: diethylether (1:3) to give as a dark green solid.

\section{DNA binding experiments}

The stock solution of DNA was prepared by dissolving DNA in $10 \mathrm{mM}$ of Tris- $\mathrm{HCl} / 100 \mathrm{mM} \mathrm{KCl}$ buffers at pH 7.4. H-telo DNA was dissolved in $10 \mathrm{mM}$ Tris-HCl/100 mM KCl (pH 7.4) buffer solution. The oligonucleotide were annealed by heating it to $90{ }^{\circ} \mathrm{C}$ for 5 minutes and then cooled to room temperature overnight. CT-DNA dissolved overnight in a $10 \mathrm{mM}$ Tris- $\mathrm{HCl} / 100 \mathrm{mM} \mathrm{KCl}(\mathrm{pH} 7.4)$ buffer solution. Then, the complexes was diluted to $5 \mathrm{mM}$ using DMSO. The absorbtion titration experiments were performed by diluting the complex with buffer to the $30 \mu \mathrm{M}$ concentrations while increasing DNA concentrations. The intrinsic binding constant $(\mathrm{Kb})$ values were calculated by the following equation 1 [15]:

$$
\frac{[\mathrm{DNA}]}{\left(\varepsilon_{\mathrm{a}}-\varepsilon_{\mathrm{f}}\right)}=\frac{[\mathrm{DNA}]}{\left(\varepsilon_{\mathrm{b}}-\varepsilon_{\mathrm{f}}\right)}+\frac{1}{\mathrm{~Kb}\left(\varepsilon_{\mathrm{b}}-\varepsilon_{\mathrm{f}}\right)}
$$

where [DNA] is the concentration of DNA in base pairs, $\varepsilon a, \varepsilon f$, and $\varepsilon b$ correspond to the $\mathrm{A}_{\text {observed }} /[\mathrm{complex}]$, the extinction coefficient of free complex and the complex in fully bound form, respectively, and $\mathrm{Kb}$ is intrinsic binding constant. A plot of [DNA]/ $(\varepsilon a-\varepsilon f)$ versus [DNA] will have a slope of $1 /(\varepsilon b-\varepsilon f)$ and intercept equal to $1 / \mathrm{Kb}(\varepsilon b-$ $\varepsilon f) . \mathrm{Kb}$ is the given ratio of the slope to the intercept.

Percentage hypochromacity was determined using the following equation 2 :

$$
\text { Hypochromacity }(\%)=\frac{\left(\varepsilon_{\mathrm{b}}-\varepsilon_{\mathrm{f}}\right)}{\varepsilon_{\mathrm{b}}} \times 100
$$

From the equation, $\mathrm{Kb}$ of complexes with G-Quadruplex DNA and CT- DNA can be calculated

\section{Results and Discussion}

Characterization study: N,N'-bis-4-(hydroxysalicylidene)-phenylenediamine-nickel(II) complex

Yield $0.386 \mathrm{~g}(77 \%) .{ }^{1} \mathrm{H}$ NMR $\left(400 \mathrm{MHz}\right.$, DMSO-d $\left.\mathrm{d}_{6}\right): \delta 6.21\left(\mathrm{~s}, 1 \mathrm{H}, \mathrm{H}^{6}\right), 6.22\left(\mathrm{~d},{ }^{3} \mathrm{~J}_{\mathrm{HH}}=8.8 \mathrm{~Hz}, 1 \mathrm{H}, \mathrm{H}^{5}\right), 7.19(\mathrm{dd}$,

$\left.{ }^{3} \mathrm{~J}_{\mathrm{HH}}=6.0 \mathrm{~Hz},{ }^{4} \mathrm{~J}_{\mathrm{HH}}=3.0 \mathrm{~Hz}, 1 \mathrm{H}, \mathrm{H}^{1}\right), 7.41\left(\mathrm{~d},{ }^{3} \mathrm{~J}_{\mathrm{HH}}=8.8 \mathrm{~Hz}, 1 \mathrm{H}, \mathrm{H}^{4}\right), 7.99\left(\mathrm{dd},{ }^{3} \mathrm{~J}_{\mathrm{HH}}=6.0 \mathrm{~Hz},{ }^{4} \mathrm{~J}_{\mathrm{HH}}=3.0 \mathrm{~Hz}, 1 \mathrm{H}\right.$, 
Roshatiara et al: INTERACTION OF N,N'-BIS[4-[1-(2-HYDROXYETHOXY)] SALICYLIDENE]PHENYLDIAMINE-NICKEL(II) AND COPPER(II) COMPLEXES WITH G-QUADRUPLEX DNA

$\left.\mathrm{H}^{2}\right), 8.54\left(\mathrm{~s}, 1 \mathrm{H}, \mathrm{H}^{3}\right){ }^{13} \mathrm{C}$ NMR (100 MHz, DMSO-d $\left.\mathrm{d}_{6}\right)$ 103.8, 108.4, 114.8, 116.0, 127.1, 136.2, 143.3, 154.9, 165.4, 167.7. IR $\left(\mathrm{cm}^{-1}\right): 3527\left(\mathrm{OH}\right.$ alcohol/phenol), $3082\left(\mathrm{C}-\mathrm{H} \mathrm{sp} \mathrm{s}^{2}\right), 1578(\mathrm{C}=\mathrm{N}), 1450(\mathrm{C}=\mathrm{C}$ aromatic $), 1121(\mathrm{C}-\mathrm{O}), 1209$ (C-N). $\mathrm{ESI}(+)-\mathrm{MS} \mathrm{m} / \mathrm{z}$ calcd for $\mathrm{C}_{20} \mathrm{H}_{14} \mathrm{~N}_{2} \mathrm{NiO}_{4}\left(\mathrm{M}^{+}\right)$: 404 a.m.u. The a.m.u. Found: $[\mathrm{M}+\mathrm{Na}]^{+}=427$ a.m.u.

N,N'-bis[4-[1-(2-hydroxyethoxy)]salicylidene]-phenyldiamine-nickel(II) complex, [2] Yield: $0.161 \mathrm{~g}, 64 \% .{ }^{1} \mathrm{H}$ NMR $\left(400 \mathrm{MHz}\right.$, DMSO-d6): $\delta 3.72\left(\mathrm{t},{ }^{3} \mathrm{~J}_{\mathrm{HH}}=4.00 \mathrm{~Hz}, 1 \mathrm{H}, \mathrm{H}^{8}\right), 4.00\left(\mathrm{t},{ }^{3} \mathrm{~J}_{\mathrm{HH}}=4.00 \mathrm{~Hz}\right.$, $\left.1 \mathrm{H}, \mathrm{H}^{7}\right), 4.96\left(\mathrm{~s}, 1 \mathrm{H}, \mathrm{H}^{9}\right), 6.32-6.39\left(\mathrm{~m}, 2 \mathrm{H}, \mathrm{H}^{4} \mathrm{H}^{6}\right), 7.24-7.26\left(\mathrm{dd},{ }^{3} \mathrm{~J}_{\mathrm{HH}}=8.0 \mathrm{~Hz},{ }^{4} \mathrm{~J}_{\mathrm{HH}}=4.0 \mathrm{~Hz}, 1 \mathrm{H}, \mathrm{H}^{1}\right), 7.46-7.48$ $\left(\mathrm{d},{ }^{3} \mathrm{~J}_{\mathrm{HH}}=8.6 \mathrm{~Hz}, 1 \mathrm{H}, \mathrm{H}^{5}\right), 8.02-8.05\left(\mathrm{~d},{ }^{3} \mathrm{~J}_{\mathrm{HH}}=8.0 \mathrm{~Hz}, 1 \mathrm{H}, \mathrm{H}^{2}\right), 8.64\left(\mathrm{~s}, 1 \mathrm{H}, \mathrm{H}^{3}\right){ }^{13} \mathrm{C}$ NMR $\left(100 \mathrm{MHz}, \mathrm{DMSO}-\mathrm{d}_{6}\right) \delta$ $59.79,70.05,102.01,108.02,115.19,116.02,127.23,135.74,142.71,154.86,165.25,167 . \mathrm{IR}_{\left(\mathrm{cm}^{-1}\right): 3352(\mathrm{OH}}$ alcohol / phenol), $3039\left(\mathrm{C}-\mathrm{H} \mathrm{sp}^{2}\right), 2878\left(\mathrm{C}-\mathrm{H} \mathrm{sp}^{3}\right) 1577(\mathrm{C}=\mathrm{N}), 1515(\mathrm{C}=\mathrm{C}$ aromatic), $1127(\mathrm{C}-\mathrm{O}), 1196(\mathrm{C}-\mathrm{N})$. $\mathrm{ESI}(+)$-MS m/z calcd for $\mathrm{C}_{24} \mathrm{H}_{22} \mathrm{~N}_{2} \mathrm{NiO}_{6}(\mathrm{M}+)$ : 492 a.m.u. The a.m.u. Found: $[\mathrm{M}+\mathrm{K}]^{+}=531,[\mathrm{M}+\mathrm{Na}]^{+}=515$ a.m.u.

N,N'-bis-4-(hydroxysalicylidene)-phenylenediamine-copper(II) complex, [3]

Yield 0.386 g (80 \%). IR (cm-1): $3350(\mathrm{OH}$ alcohol / phenol), $3150(\mathrm{C}-\mathrm{H} \mathrm{sp} 2), 1581(\mathrm{C}=\mathrm{N}), 1448(\mathrm{C}=\mathrm{C}$ aromatic), $1122(\mathrm{C}-\mathrm{O})$. $\mathrm{ESI}(+)-\mathrm{MS} \mathrm{m} / \mathrm{z}$ calcd for $\mathrm{C}_{20} \mathrm{H}_{14} \mathrm{CuN}_{2} \mathrm{O}_{4}\left(\mathrm{M}^{+}\right)$: 409 a.m.u. The a.m.u. Found: $[\mathrm{M}+\mathrm{Na}]^{+}=432$ a.m.u.

N,N'-bis[4-[1-(2-hydroxyethoxy)]salicylidene]-phenyldiamine-copper(II) complex, [4]

Yield: $0.161 \mathrm{~g}, 74 \%$. IR (cm-1): 3350 (OH alcohol / phenol), $3100\left(\mathrm{C}-\mathrm{H} \mathrm{sp}{ }^{2}\right), 2929\left(\mathrm{C}-\mathrm{H} \mathrm{sp}{ }^{3}\right) 1575(\mathrm{C}=\mathrm{N}), 1482$ $\left(\mathrm{C}=\mathrm{C}\right.$ aromatic), $1187(\mathrm{C}-\mathrm{O})$. ESI(+)-MS m/z calcd for $\mathrm{C}_{24} \mathrm{H}_{22} \mathrm{CuN}_{2} \mathrm{O}_{6}\left(\mathrm{M}^{+}\right): 497$ a.m.u. The a.m.u. Found: $[\mathrm{M}+\mathrm{K}]^{+}=536$ a.m.u.

The N,N'-bis-4-(hydroxysalicylidene)-phenylenediamine-nickel(II) complex had been successfully synthesized characterized. The attachment of hydroxyl was then carried out by adding 2-chloroethanol in presence of potassium carbonate. The reaction scheme of hydroxyl substituted Nickel(II)- and Copper(II)- salphen complexes [2] and [4] are illustrated in Figure 1. The synthesis and characterization of complex [1], [2] and [3] have been reported in our previous work [14]. Synthesis of complex [4] yielded 74\% product as dark green solid. Complex [4] was characterized by means of FTIR and mass spectrometry. Based on IR spectra of the complex [4], absorption bands corresponding to $\mathrm{Cu}(\mathrm{II})$ salphen due to stretching vibrations of some functional group such as imine, $\mathrm{C}-\mathrm{O}$ hydroxyl and $\mathrm{C}=\mathrm{C}$ for aromatic group are presence. The expected band for imine $\mathrm{C}=\mathrm{N}$ appears at $1575 \mathrm{~cm}^{-1}$ suggested the formation of the salphen complex. The IR spectrum also displayed bands at $3352 \mathrm{~cm}^{-1}, 1482 \mathrm{~cm}^{-1}$ and $1187 \mathrm{~cm}^{-1}$ for hydroxyl, $\mathrm{C}=\mathrm{C}$ aromatic and $\mathrm{C}-\mathrm{O}$ respectively. The attachment of hydroxyl side chain to complex [2] to yield complex [4] was successful evidence by the presence of absorption band at $2929 \mathrm{~cm}^{-1}$ which can be assigned to C-H $\mathrm{sp}^{3}$. The electrospray ionization mass spectrometry (ESI-MS) was carried out to determine the mass-to-charge ratio of complex [4]. Spectrum showed that one peak corresponding to complex with adducts ion, which is $[\mathrm{M}+\mathrm{K}]^{+}=536$ a.m.u. Since the copper(II) complex is paramagnetic, NMR spectroscopy could not be used to analyze the complex.

\section{UV-Vis DNA titration}

UV-Vis spectroscopic titration were carried out to gain inside into the binding mode and binding affinity of the complexes with G-Quadruplex and CT- DNA. When a compound exhibit a high binding affinity, it is said to be a powerful binder to DNA and a promising candidate as an anticancer drug. The UV-vis spectra for titration study complex [2] with G-Quadruplex DNA is given in Figure 2. As shown, complex [2] at $30 \mu \mathrm{M}$ showed maximum absorption peak at $388 \mathrm{~nm}$. The intensity of complex decreases with addition of G-Quadruplex DNA and red shift can be seen with further addition of DNA. Obviously hypchromicity of 53\% was observed along with $10 \mathrm{~nm}$ bathochromic shift. The hypochromism effect and bathochromic shifting suggest end stacking for the binding mode of the complex toward G-quadruplex DNA [16]. 


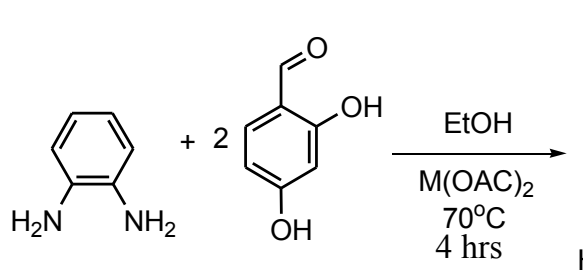

HO<smiles>Oc1ccc2c(c1)O[N+]1(Oc3ccccc31)N(c1ccccc1)C=C2</smiles>

[1] $\mathrm{M}=\mathrm{Ni}(\mathrm{II})$

[3] $\mathrm{M}=\mathrm{Cu}(\mathrm{II})$

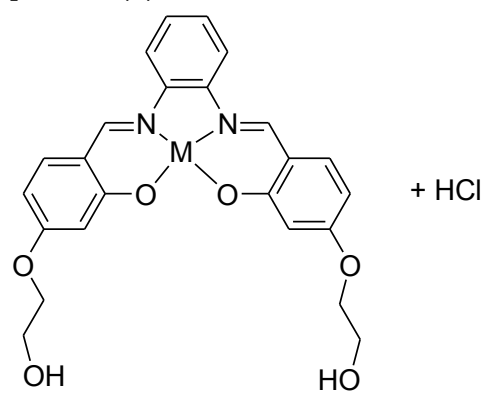

[2] $\mathrm{M}=\mathrm{Ni}(\mathrm{II})$

[4] $\mathrm{M}=\mathrm{Cu}(\mathrm{II})$

Figure 1. Reaction scheme for N,N'-bis[4-[1-(2-hydroxyethoxy)]salicylidene]-phenyldiamine-nickel(II) and copper(II) complex
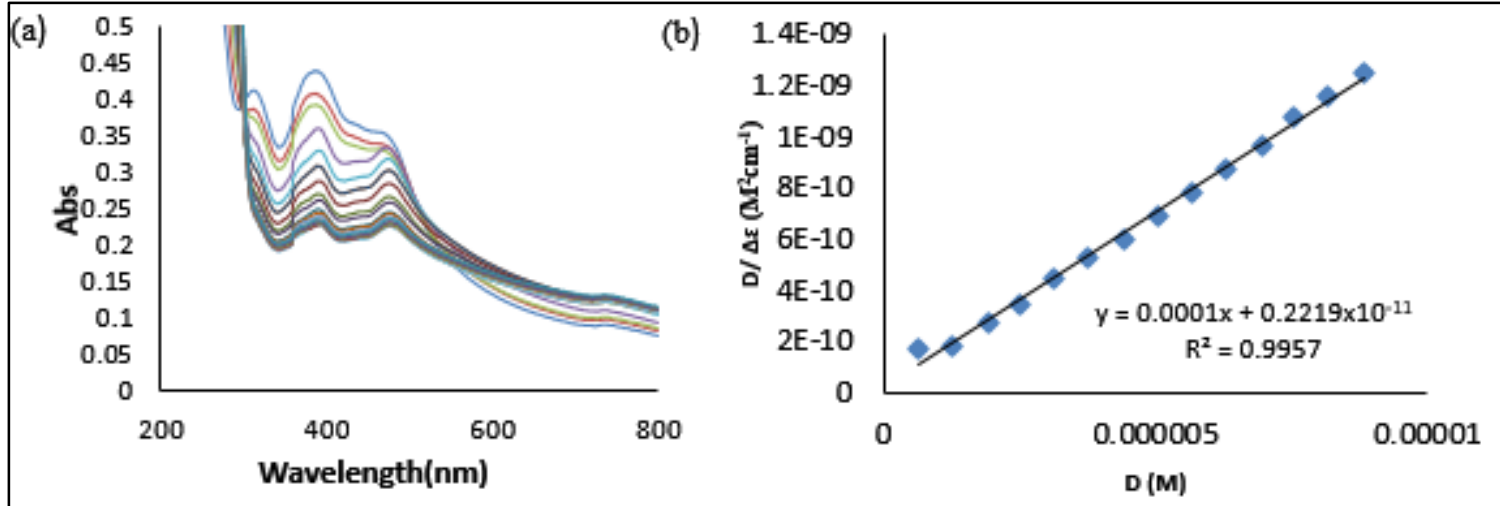

Figure 2. (a) Absorption spectral changes of complex [2] $(30 \mu \mathrm{M})$ in Tris/ $\mathrm{KCl}$ buffer $(\mathrm{pH} 7.4)$ in the absence and presence of increasing concentration of H-Telo $\left(6.30 \times 10^{-3} \mathrm{mM}-1.3 \times 10^{-3} \mathrm{mM}\right)$, (b) The reciprocal plot that fits the absorbance data to obtain the binding constant.

The next binding study is complex [4] with G-Quadruplex DNA (Figure 3). Referring to the spectra, complex [4] alone at $30 \mu \mathrm{M}$ showed maximum absorption peak at $385 \mathrm{~nm}$. The intensity of complex decrease with addition of G-Quadruplex DNA and small red shift appeared with further addition of DNA. A hypochromic effect 16\% was observed along with $6.5 \mathrm{~nm}$ bathochromic shift. The hypochromism effect and bathochromic shifting suggesting the complex possesed end stacking mode binding which is same mode with complex [2] when binding to G-quadruplex DNA. 

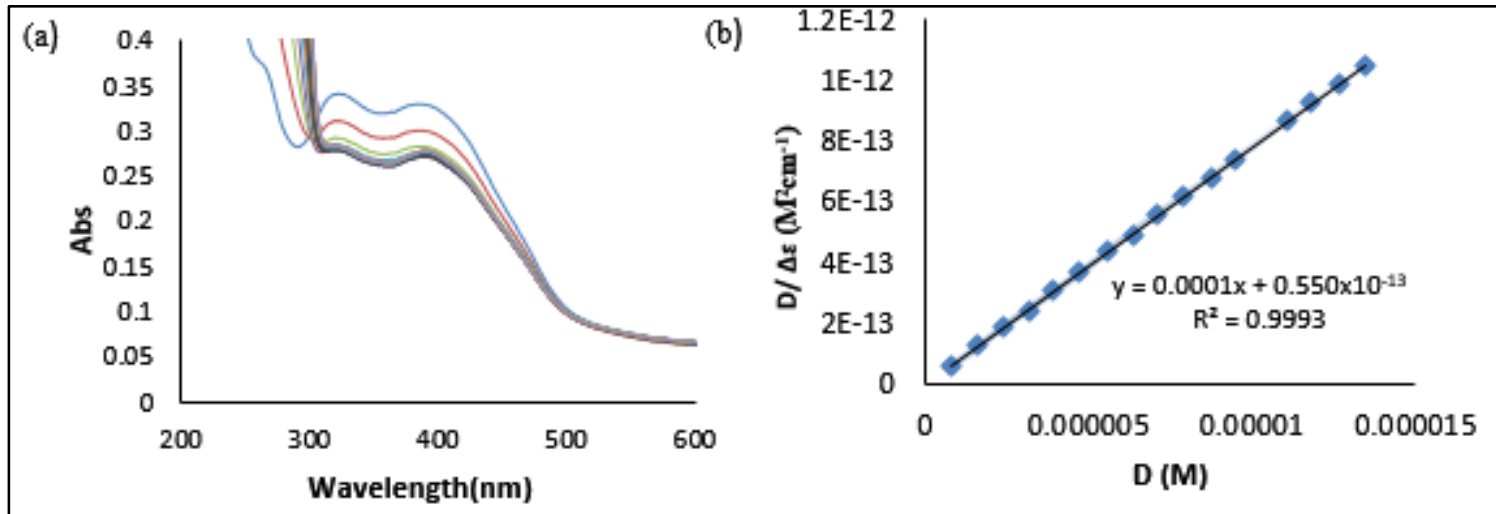

Figure 3. (a) Absorption spectral changes complex [4] $(30 \mu \mathrm{M})$ in Tris/ $\mathrm{KCl}$ buffer $(\mathrm{pH} 7.4)$ in the absence and presence of increasing concentration of H-Telo $\left(7.9 \times 10^{-3} \mathrm{mM}-13.4 \times 10^{-3} \mathrm{mM}\right)$, (b) The reciprocal plot that fits the absorbance data to obtain the binding constant

By using the Scatchard equation (the plot of $\mathrm{D} / \Delta \varepsilon$ ap versus $\mathrm{D}$ ) the binding constant $(\mathrm{Kb})$ values of the compounds to G-quadruplex DNA were calculated. Complex [2] was found to bind to G-quadruplex DNA with higher affinity $\left(\mathrm{Kb}=5.42 \pm 2.48 \times 10^{6} \mathrm{M}^{-1}\right)$ compared to the complex [4] $\left(\mathrm{Kb}=1.42 \pm 2.48 \times 10^{6} \mathrm{M}^{-1}\right)$. Both new salphen complexes with hydroxyl substituted showed significant improvement on G-quadruplex DNA stabilization ability compared to piperidine substituted metal complexes that have been reported before [5].

For comparison, we also study the binding affinity of both complexes with duplex calf thymus DNA (CT-DNA). The concentration of CT-DNA was determined from UV absorbance at $260 \mathrm{~nm}\left(\varepsilon=6600 \mathrm{~cm}^{-1}\right)$. The absence of any protein contamination with CT DNA was confirmed from absorption ratio at 260 and $280 \mathrm{~nm}$ which was found to be 1.86 [17]. In Figure 4, we can see that upon addition of CT- DNA to complex [2], hypochromicity (29\%) of peak absorption can be observed with small red shift $(3 \mathrm{~nm})$. From the observations, it is concluded that complex [2] have been intercalated to the base pairs of CT-DNA [18].

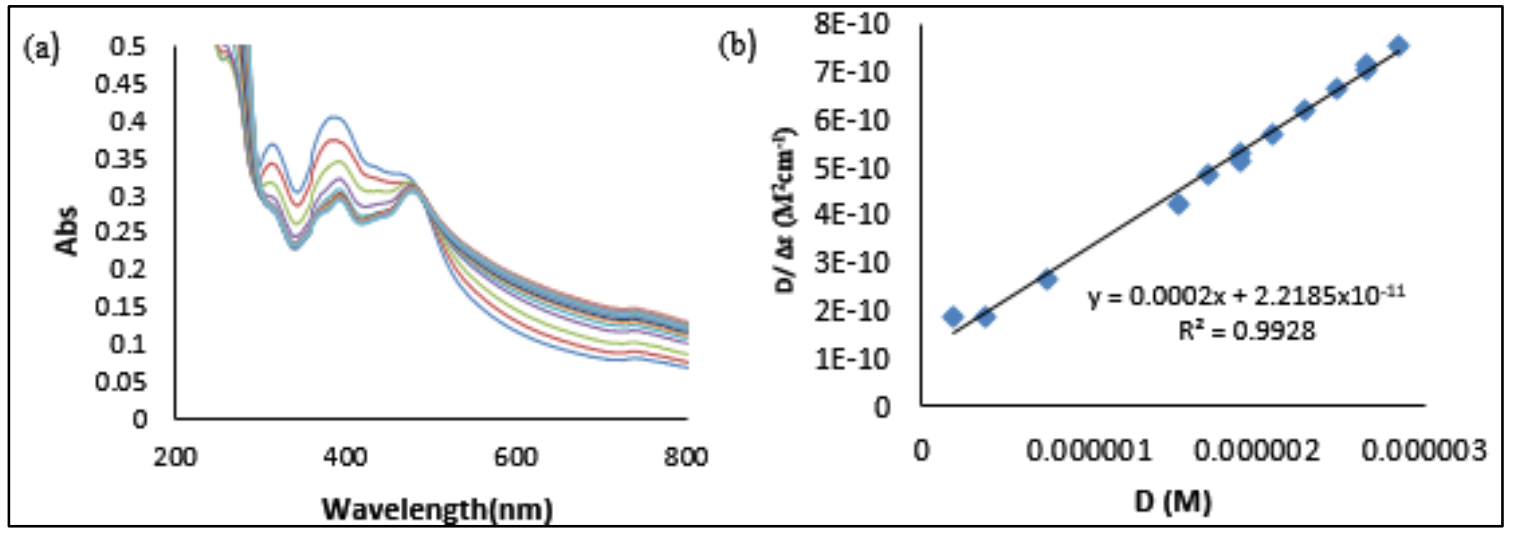

Figure 4. (a) Absorption spectral changes of complex [2] $(30 \mu \mathrm{M})$ in Tris/ $\mathrm{KCl}$ buffer $(\mathrm{pH} 7.4)$ in the absence and presence of increasing concentration of CT-DNA $\left(0.19 \times 10^{-3} \mathrm{mM}-3.61 \times 10^{-3} \mathrm{mM}\right)$, (b) The reciprocal plot that fits the absorbance data to obtain the binding constant 
The binding study of complex [4] with CT-DNA was shown in Figure 5. Upon addition of CT-DNA to solutions of complex [4] the hypochromic (13\%) followed by small bathochromic effect $(3.5 \mathrm{~nm})$ can be seen. These spectral characteristics suggested moderately intercalative mode binding.

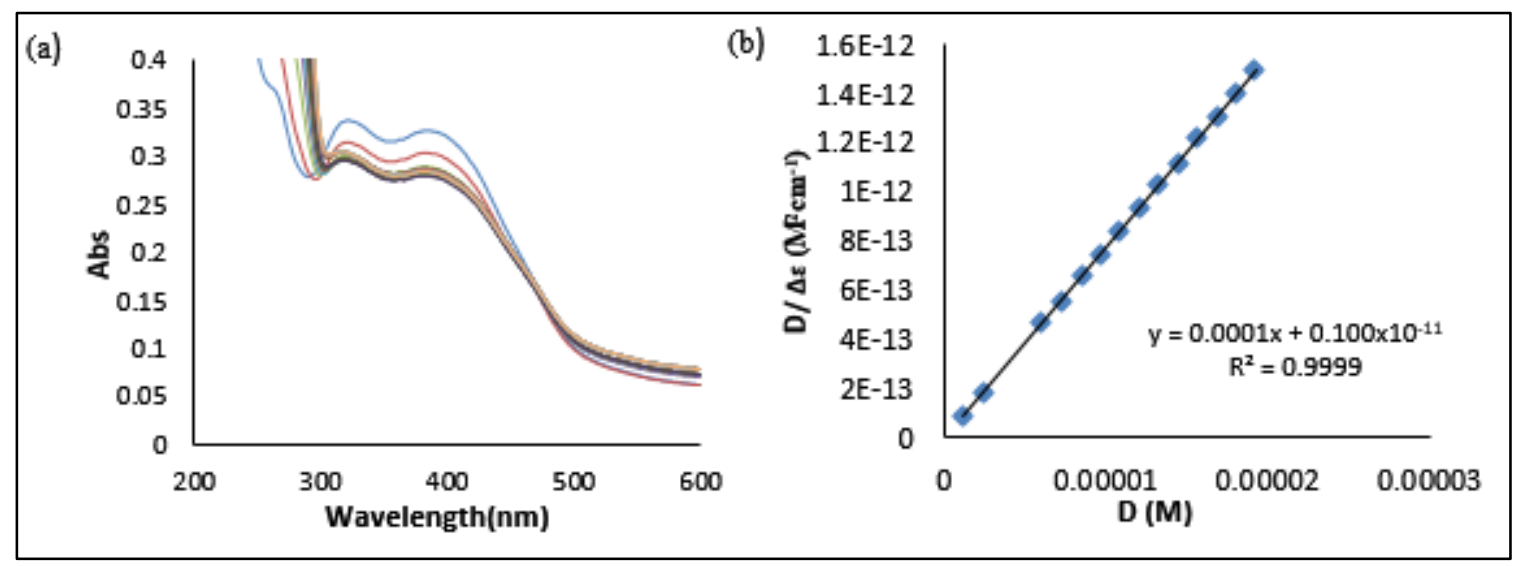

Figure 5. (a) Absorption spectral changes of complex [4] $(30 \mu \mathrm{M})$ in Tris/ $\mathrm{KCl}$ buffer $(\mathrm{pH} 7.4)$ in the absence and presence of increasing concentration of CT-DNA $\left(1.2 \times 10^{-3} \mathrm{mM}-20.4 \times 10^{-3} \mathrm{mM}\right)$, (b) The reciprocal plot that fits the absorbance data to obtain the binding constant.

From the equation, calculated intrinsic binding constant, $\mathrm{Kb}$ of complex [2] and [4] with CT- DNA are $2.51 \times 10^{6} \pm$ $0.65 \mathrm{M}^{-1}$ and $7.80 \times 10^{5} \pm 0.65 \mathrm{M}^{-1}$. Both complexes show selectivity for G-quadruplex DNA over CT- DNA by 2.15- and 1.82-fold, respectively. The presence of hydroxyl substituent on the metal salphen complexes seems to have little effect in the selectivity towards G- quadruplex DNA over CT- DNA.

\section{Conclusion}

N,N'-bis[4-[1-(2-hydroxyethoxy)]salicylidene]-phenyldiamine-nickel(II) complex and N,N'-bis[4-[1-(2hydroxyethoxy)] salicylidene]-phenyldiamine-copper(II) complex have been successful synthesized and characterized. The DNA binding of complex with G-quadruplex DNA and CT-DNA examine by absorption spectral technique. From the results, the binding constant interaction between complex [2] and [4] with G quadruplex DNA are $(5.42 \pm 2.48) \times 10^{6} \mathrm{M}^{-1}$ and $(1.42 \pm 2.48) \times 10^{6} \mathrm{M}^{-1}$. Meanwhile, the binding constant of complex [2] and [4] with CT-DNA are $(2.51 \pm 0.65) \times 10^{6} \mathrm{M}^{-1}$ and $(7.80 \pm 0.65) \times 10^{5} \mathrm{M}^{-1}$ respectively. The UV-Vis titration study suggested that complex [2] binds selectively to G-quadruplex DNA over CT-DNA by two folds. Complex [2] showed the potential to be a good candidate for anti-cancer drug development via inhibition of telomerase activity.

\section{Acknowledgement}

The authors gratefully acknowledge The National University of Malaysia for providing the research facilities. This work has been carried out with the support of Malaysian Government through Ministry of Higher Education grant GUP-2015-044 and DPP 2014-016.

\section{References}

1. Thomas, P. G., Huw, E. L. W., Katarzyna, I. G., Stephen, R., Neil, J. O., Malcolm, F. G. S., John, E. M. and Mark S. S. (2009). Selectivity of small molecule ligands for parallel and anti-parallel DNA G-quadruplex structures. Organic and Biomolecular Chemistry, 7: 4194 - 4200.

2. Xu-Jian, L., Qi-Pin, Q., Yu-Lan, L., Yan-Cheng, L. and Hong L. (2014). Synthesis, antitumor activity and GQuadruplex DNA/ct-DNA binding property of cationic platinum(II) complex of 2-(4-nitro)-imidazo-[5,6f][1,10]-phenanthroline. Indian Journal of Chemistry, 53: 787 - 792. 
3. Hasani, L., Hakimian, F. and Safaei, E. (2014). Spectroscopic investigation on the interaction of copper porphyrazines and phthalocyanine with human telomeric G-Quadruplex DNA. Biophysical Chemistry, 187: $7-13$.

4. Nurul, H. A. K., Oscar, M., Arun, S., Alenxander, J. T., Sushobhan, G., Marina, K. K. and Vilar, R. (2014). Salphen metal complexes as tunable G-quadruplex binders and optical probes. RSC Advances, 4: 3355 - 3363.

5. Nancy, H. C., Nurul, H. A. K., Gary, N. P., Mekala, G., Vanessa, P., Alan, K. T., Ramon, V. and Stephen, N. (2012). Molecular basis of structure-activity relationships between salphen metal complexes and human telomeric DNA quadruplexes. Journal of Medical Chemistry, 55: $209-222$.

6. Sofia, G., Inês, R., Filipa, M., Isabel, C. S., Elisabetta, G., Beata, K., Jorge, G-C., Mauro, R., Ramon, V. and António P. (2016). Anthracene-terpyridine metal complexes as new G-quadruplex DNA binders. Journal of Inorganic Biochemistry, 160: 275 - 286.

7. Ang, D. L., Harper, B. W., Cubo, L., Mendoza, O., Vilar, R., \& Aldrich-Wright, J. (2016). Quadruplex DNAstabilising dinuclear platinum (ii) terpyridine complexes with flexible linkers. Chemistry-A European Journal, 22(7), $2317-2325$.

8. Taetz, S., Murdter, T. E., Zappc, J., Boettcher, S., Baldes, C., Kleideiter, E., Piotrowska, K., Schaefer, U. F., Klotz, U., Lehr and C.-M. (2008). Decomposition of the telomere-targeting agent BRACO19 in physiological media results in products with decreased inhibitory potential. International Journal of Pharmaceutics, 357: $6-14$.

9. Julie, E. R., Stephen, N. and Ramon, V. (2007). Stabilisation of human telomeric quadruplex DNA and inhibition of telomerase by a platinum phenanthroline complex. Chemical Communications, 42: 4366 - 4368 .

10. Siti, N. H, Yaakob, R. and Haslina, A. (2016). Synthesis, characterization and DNA binding activity of a potential DNA intercalator. Malaysian Journal of Analytical Sciences, 20(4): 760 - 769.

11. Fun, H. K., Kia, R., Mirkhani, V. and Zargoshi, H. (2008). \{5, 5-Dihydroxy-2, 2-[o-phenylenebis (nitrilomethylidyne)] diphenolato n nickel (II) dihydrate. Acta Crystallographica Section E: Structure Reports Online, 64(9): $1181-1182$.

12. Verity S. S., Kogularamanan S., Arun S., Andrew J. P. W., David J. M. and Ramon V. (2015). Syntheses of polypyridyl metal complexes and studies of their interaction with quadruplex DNA. Dalton Transactions (RSC Publishing), 44: 3686 - 3700

13. Nurul Huda Abd Karim (2012). Studies towards elucidating the binding modes between metal-salphen complexes and G-quadruplex DNA. Thesis Doctor of Philosophy, Imperial College London.

14. Roshatiara, S. and Nurul Huda, A. K. (2016). Synthesis and characterization of N,N'-bis[4-[1-(2hydroxyethoxy)]salicylidene]-phenyldiamine-nickel(II)] complex. AIP Publishing, 1784: 030007

15. Subbaraj, P., Ramu, A., Raman, N. and Dharmaraja, J. (2015). Synthesis, characterization, DNA interaction and pharmacological studies of substituted benzophenone derived Schiff base metal(II) complexes. Journal of Saudi Chemical Society, 19: $207-216$.

16. Krishnamoorthy, P., Sathyadevi, P., Alan, H. C., Rachel, R. B. and Dharmaraj, N. (2011). Evaluation of DNA binding, DNA cleavage, protein binding and in vitro cytotoxic activities of bivalent transition metal hydrazone complexes. European Journal of Medicinal Chemistry, 46: 3376 - 3387.

17. Selamat, N., Heng, L. Y., Hassan, N. I. and Karim, N. H. A. (2016). Synthesis and Characterization of 6, 6' -bis (2-hydroxyphenyl)-2, 2'-bipyridyl ligand and its platinum complex for the interaction with CT-DNA. Malaysian Journal of Analytical Sciences, 20(1): 111 - 120.

18. Bordbar, M., Khodaie, F., Tabatabaee, M., Yeganeh-Faal, A., Mehri lighvan, Z. and Mohammad-Ganji, S. (2016). Interaction studies of DNA binding with new $\mathrm{Cu}(\mathrm{II})$ complex by spectrophotometric, spectrofluorometric, voltammetric and circular dichroism techniques. Bulgarian Chemical Communication, 48(3): $422-429$. 